\title{
Motivation of Farmers toward Tobacco Farming in Sleman District, Sleman Regency
}

\author{
Indardi ${ }^{*}$ and Dwi Ramadianti \\ Department of Agribusiness, Universitas Muhammadiyah Yogyakarta, Yogyakarta, Indonesia
}

\begin{abstract}
This study aims to determine the motivation of farmers in tobacco farming in Sleman District, Sleman Regency. The research location was chosen because people who cultivate tobacco have the highest productivity (2.4883 tons/ha) in 2019 in Sleman Regency. The tobacco farmers in Sleman District are members of the PAC Farmer Group (Branch Management) of the Indonesian Tobacco Farmers Association, Sleman District. Respondents were determined by census, namely 34 farmers. The analysis used in this research is descriptive analysis with scoring technique. This study uses ERG motivation theory. The results showed that the existence motivation indicator obtained an average score of 3.83 (including the high category), the relatedness motivation indicator obtained an average score of 3.69 (including the high category), as well as the growth motivation indicator obtained a score of 3.74. (Also included in the high category). So it can be concluded that farmers in Sleman District in tobacco farming can be said to have high motivation, both in fulfilling daily needs (existence), interacting with other people (relatedness) and in the need to develop (growth).
\end{abstract}

\section{Introduction}

Sustainable agriculture supposed by the government, a change in land use has become an important issue to be taken into account as such that the change does not tend to damage the environment [1]. Biodiversity declines in farmland have been attributed to intensification of farming at the field level and loss of heterogeneity at the landscape level. However, farmers are not solely optimizing production; their actions are also influenced by social factors, tradition and interest in nature, which indirectly influence biodiversity but rarely are incorporated in studies of farmland biodiversity [2]. Population growth in Indonesia and other countries has a need for tobacco every year tends to increase [3]. Tobacco is the raw material for making cigarettes, especially for the development of the cigarette industry in Indonesia, the existence of tobacco plants is important to note and improve so that the increasing demand for tobacco, the presence of tobacco will never subside with good cultivation. Yogyakarta Special Region is the second-largest tobacco producer after East Java with an average area of 55,000 hectares and an average production of 40.040 tons per year, or by $23.5 \%$ and $21.47 \%$ of the total area and national production [4]. Yogyakarta Province has four regencies and one city, namely Sleman, Bantul,

\footnotetext{
*Corresponding author: indardi@umy.ac.id
} 
Kulonprogo, Gunung Kidul and Yogyakarta City. Of the five districts/cities are one of the plantation crop-producing districts especially tobacco plant is Sleman District. Sleman Regency is one of the regencies in Yogyakarta which has 17 sub-districts in which several sub-districts of which, the people work as tobacco farmers with good quality results, and even have been supplied to a number of large cigarette companies. The sub-districts that have this shooting production are Seyegan, Mlati, Prambanan, Kalasan, Ngemplak, Ngaglik, Sleman, Tempel and Cangkringan. Based on BPS data from Sleman Regency, it shows that of a number of tobacco producing sub-districts, the highest tobacco productivity of 2.4883 tons/ha in 2019 was found in Sleman District, with the lowest productivity of 0.1681 tons/ha found in Cangkringan District [5]. Tobacco commodity is a phenomenal plantation product. On the one hand, it is a cigarette producing commodity that is not good for health, on the other hand it is seen as a plantation commodity with high economic value. The interesting thing with the high productivity of the tobacco commodity in Sleman District, it turns out that the farmers are members of the PAC Farmer Group (Branch Management Committee) of the Indonesian Tobacco Farmers Association, Sleman District. It appears that tobacco farming is carried out more intensively and professionally. The interesting thing that becomes a question is whether high tobacco productivity is driven by performance in farming solely motivated to get high profits (economic motives) or whether there are other motivations so that the farming produces high productivity. The novelty of this research, on the research subject of tobacco farmers who are members of the farmer groups of the sub-branches of the Indonesian Farmers Association with an ERG motivational theory approach. Related to this, researchers are interested in studying the motivation of farmers to cultivate tobacco in Sleman District by being approached using the ERG motivation theory.

\subsection{Tobacco Farming}

Farming is an effort to manage the natural resources needed for agricultural products such as the need for land and water, improvements made to the land itself, sunlight, buildings that stand on the ground. Farming science is defined as the effective and efficient allocation of existing resources with the aim of obtaining high profits at a certain time [6]. Land is a determinant in farming, which in general can be seen that the wider the area of land that is cultivated, the greater the amount of production produced. According to [7], the status of land ownership is a relation of farming and processing, so that it is known that there are several types of land status such as property rights land, rental land, and profit sharing land. Tobacco is one of the plantation crop commodities that promises to have a variety of high profits. Tobacco as one of the sources of raw materials for making cigarettes which is the result of domestic production. In Africa, Most African governments promote tobacco farming as a way to alleviate poverty [8]. In Pakistan The Tobacco Industry provides job opportunities for many people involved in the agriculture, production and trade of Tobacco products in Pakistan [9]. Tobacco remains a dominant cash crop in many low- and middleincome countries, despite the evidence suggesting that it is not as profitable as industry claims and is harmful to health and the environment [10]. a study in bangladesh showed that Tobacco cultivation incurs very high environmental costs that cause harm to society [11]. Studies in rural Piere, northern Greece show that the constant emphasis on the basic safety precautions required when using pesticides and the importance of protective equipment is essential to change farmers' wrong habits that can put their health at risk [12]. Tobacco cultivation includes seeding, tillage, planting and maintenance, pest and disease control, and harvesting and post-harvesting. For the sustainability of good tobacco cultivation, it is necessary to follow good governance. Better governance, together with sustainability land management strategies and livelihood diversification strategies, can 
reduce dependency on tobacco cultivation and contribute to a sustainable future for this ecoregion [13]. so it is important to carry out agricultural activities through the "ecology" of agricultural policies the objectives of this policy are to protect environmentally sensitive areas, to improve groundwater quality and, more recently, to develop organic agriculture and/or reduce pesticide use [14].

\subsection{Motivation Theory}

Motivation is etymologically derived from the word motive which conditioned the meaning of encouragement. Motive is defined as the power contained within a person to encourage him to take action (driving force). Motivation is a potential force that exists within a human being, which can be developed independently or developed by a number of external forces which essentially revolve around monetary rewards and non-monetary rewards, which can affect the results of their performance positively or negative, which depends on the situation and conditions faced by the person concerned. Motivation is an impulse or reason that moves each individual to behave. especially motivating the younger generation to encourage young people motivation of farmers by strengthening their role by increasing knowledge of the horticultural business, including training, internships, and discussions about technological developments by utilizing the younger generation on regular basis farmer group meeting [15]. Motivation is a result arising from a person's interaction in certain situations he faces. Consideration motivation that is trying to understand how different cognitive framworks inform and shape attitudes. Its purpose is to provide insight into why, when two farmers in it seems that an identical situation is encountered with the same opportunity, a farmer chooses to chase it and oyhers don't [16]. Motives can be divided into three types, namely biogenetic motives, sociogenetic motives and theological motives [17]. The results show that economic motivation (growth), health (growth), safety issues (existence) and environmental issues (relatedness) are the main motives for conversion, while social and ethical motives (relatedness) are less important [18]. In particular, the health motivation in the study of consumption of organic food is mainly based on avoidance of chemicals residues, antibiotics, hormones, genetically modified organisms, and disease [19]. In the study of motivations for organic farming in Nepal, all individuals involved in organic farming have some common motivations, such as a desire for personal health, quality products and rural development [20]. In a study of farmers market perceptions and motivations in sydney found that buyers are motivated by a variety of social, ethical, health, and environmrntal factors [21]. In a study of motivation and attitudes towards organic buying in Scotland showed that consumer buying motivation is self-interested (feeling better, safer) rather than altruistic [22]. in the study of motivations for sustaining urban farming participation in selangor malaysia showed that physical and mental health (existence motivation) and environment (relatedness motivation) became the motivation with the highest score among urban farming practitioners [23]. In studying farmer's motivation to employ sustainable production techniques in agriculture, mainstream researchers have identified that a single and unique motivation is rarely found; rather among most farmers a bundle of motivations [24]. Based on the source, the motives are divided into two, namely intrinsic motives and extrinsic motives. Findings of the study showed that VFTs were motivated by a combination of intrinsic and extrinsic factors [25]. on research on motivation of organic rice farmers in Klaten use Maslow's needs theory, intending to describe the motivation of farmers in organic rice farming [26].

\section{Method}


The method used in this research is descriptive analytical method on a census basis with respondents to 34 farmers who are members of the APTI (Indonesian tobacco farmers association) PAC (subsidisry board) group. This study will describe a systematic description of the motivation of farmers in tobacco farming in Sleman Sub-district, Sleman Regency. This location was chosen because observations Sleman is a district that has the productivity of the most high among the 17 districts in the regency of Sleman. High productivity of tobacco farmers illustrates that farmers have a hard and earnest effort in farming, which they do because they have a strong motivation. The important question is that farmers in tobacco farming are only based on one motivation or because of various motivations. This study uses an ERG (Existence, Relatedness and Growth) Motivation Theory approach. Existence motivation is motivation based on the encouragement of farmers to meet the needs of: a) food, b) clothing and housing, c) education costs and d) saving. Motivation Relatedness is a motivation that is based because of the encouragement of farmers to meet the needs of: a) having a relationships with others, b) expand relationship with the group, c) cooperation by farmers another, and d) having a relationship with the extension. Furthermore, to Motivation Growth is based motivation because of the encouragement of farmers to meet the needs of: a) Enhancing the skills of farming, b) buy tertiary goods, c) Valued and respected, d) Motivation for health, and e) own or develop a business. Theoretically, [27] reveals that there are five categories of measurement ranging from very low to very high, as presented in table one. Furthermore, in measuring the level of motivation of farmers in tobacco farming, both for indicators of existence motivation, relatedness motivation and growth motivation refer to on the grouping of scores from each class interval and making the category refers to what Sugiono said.

Table 1. Interpretation of determining the level of criteria for each indicator

\begin{tabular}{|c|c|c|l|}
\hline No. & Score Range (1-5) & In Percent (\%) & Category \\
\hline 1. & $1.00-1.80$ & $0.00-20.00$ & Very Low \\
\hline 2. & $1.81-2.60$ & $20.01-40.00$ & Low \\
\hline 3. & $2.61-3.40$ & $40.01-60.00$ & Fairly High \\
\hline 4. & $3.41-4.20$ & $60.01-80.00$ & High \\
\hline 5. & $4.21-5.00$ & $80.01-100.00$ & Very High \\
\hline
\end{tabular}

Source: [27]

Respondents were taken by census, namely by taking all the farmers ( 34 votes farmers) who are involved in farming activities existing tobacco and incorporated in Farmers Group PAC (Board Child Branch) APTI (Tobacco Growers Association Indonesia) in the District Sleman, Sleman Regency. Overall tobacco farmers who are members of the PAC farmer groups totaling 34 people made as respondents in this study.

\section{Results}

Motivation is a collection of forces or drives that cause farmers to behave in a certain way to do something they want. In doing work everyone has different motivations, as well as farmers. Farmers run tobacco farming to fulfill their various needs. In this study, farmers' motivation was measured using the theory of ERG which includes 3 indicators of motivation, namely to fulfill the need for existence, to fulfill the need for relatedness, and to fulfill the need for growth.

Indicator of Fulfillment of Existence Needs (Existence). If seen in Table 2 (existence motivation) and table 3 (relatedness motivation) both show the category of high motivation. This is in accordance with the results of Jostein Vik's study which shows that social motivation is as important as economic motivation [28]. The need for existence (existence) is a need that encourages farmers to fulfill their daily life needs which consist of meeting 
the needs of a) family food in their daily life, b) clothing and housing (such as buying clothes and repairing housing), c) fulfillment education of their children and d) to meet the needs that will become (by way of opening a bank account and have a family life insurance.

Results of research on Table two shows that the motivation of top farmers in farming tobacco in the district of Sleman is to meet the food needs of families both in terms of quantity which is to meet the needs of food three times a day with an average score of supreme 4:35, and in terms of quality that is to food needs healthy and nutritious with the average acquisition score of 4:26. Food is the most basic need and the first that humans need to be able to continue their life. The need for family food is a basic need for humans to be able to survive, this need that must be met by tobacco farmers in Sleman to support their families every day. Food is needed in terms of quantity or quality. It is clear that the motivation of farmers in tobacco farming in Sleman District is the first to be driven to meet the family's food needs three times a day and the second is to be motivated to meet the needs of healthy and nutritious food. Farmers have elling trees trimming logs have a sense of responsibility is very large in sufficient family consumption needs her.

Table 2. Scores obtained and categories of motivation for the fulfillment of the needs of existence

\begin{tabular}{|c|c|c|c|c|}
\hline No. & Parameter & $\begin{array}{l}\text { Score } \\
\text { Range }\end{array}$ & $\begin{array}{c}\text { score } \\
\text { obtained }\end{array}$ & Motivation Category \\
\hline \multirow[t]{3}{*}{1.} & $\begin{array}{l}\text { Motivation to meet family food } \\
\text { needs }\end{array}$ & & & \\
\hline & $\begin{array}{l}\text { a. Encouraged to meet the family's } \\
\text { food needs three times a day }\end{array}$ & $1-5$ & 4.35 & Very high \\
\hline & $\begin{array}{l}\text { b. Encouraged to meet the needs of a } \\
\text { healthy and nutritious food }\end{array}$ & $1-5$ & 4.26 & Very high \\
\hline \multirow[t]{3}{*}{2} & $\begin{array}{l}\text { Motivation to meet the needs of } \\
\text { family clothing and housing }\end{array}$ & & & \\
\hline & $\begin{array}{l}\text { a. Driven to meet the family's } \\
\text { clothing needs in the form of } \\
\text { clothing }\end{array}$ & $1-5$ & 3.97 & High \\
\hline & $\begin{array}{l}\text { b. Driven to meet the needs of the } \\
\text { board (housing) }\end{array}$ & $1-5$ & 3.88 & High \\
\hline \multirow[t]{3}{*}{3} & $\begin{array}{l}\text { Motivation to meet children's } \\
\text { education costs }\end{array}$ & & & \\
\hline & $\begin{array}{l}\text { a. Driven to meet children's } \\
\text { education costs }\end{array}$ & $1-5$ & 4.18 & High \\
\hline & $\begin{array}{l}\text { b. Encouraged to meet the costs of } \\
\text { supporting children's education in the } \\
\text { form of bags, school clothes, shoes, } \\
\text { and learning tools }\end{array}$ & $1-5$ & 4.24 & Very high \\
\hline \multirow[t]{3}{*}{4} & Motivation to meet future needs & & & \\
\hline & $\begin{array}{l}\text { a. Encouraged to have savings in the } \\
\text { bank for future needs }\end{array}$ & $1-5$ & 3.06 & Enough \\
\hline & $\begin{array}{l}\text { b. Encouraged to have life insurance } \\
\text { for the family }\end{array}$ & $1-5$ & 2.59 & Low \\
\hline \multicolumn{2}{|c|}{ Amount } & 8-40 & $\mathbf{3 0 . 5 3}$ & High \\
\hline
\end{tabular}

Meeting the needs of clothing and family housing is the second parameter after food, which is a parameter, used by farmers to determine the level of motivation of farmers in tobacco farming in Sleman District. The need for clothing and housing is also a primary need that must be fulfilled and is an important need for the continuity of a normal life for the community, especially for tobacco farmers in Sleman District. Farmers are encouraged to meet the family's clothing needs in the form of clothing with an average score of 3.97 
(including the high category). This shows that clothing is also a priority for farmers to fulfill both for daily wear and clothing for certain events. Tobacco farmers in Sleman subdistrict are also encouraged to fulfill their housing needs (including house renovation) with an average score of 3.88 (included in the high category). This shows that the fulfillment of housing needs, including house repairs/renovations, is seen as important for farmers to fulfill. The board is an important need, because it is a place where farmers and their families can take shelter and shelter from hot and rainy conditions. Besides that, it is also to maintain the dignity of the family and is very important in providing comfort for the family in carrying out their lives.

Fulfillment of educational costs of children is a parameter which is the third to determine the extent of motivation of farmers in tobacco farming in Sleman sub-district, Sleman Regency. Education is important for every individual, education is a process of personality formation for a child. Through education a child will learn and acquire knowledge, forming attitudes better, have a better perspective and can even get a new talent. In the parameter of motivation to meet the cost of children's education, determine how much motivation level of farmers in tobacco farming in Sleman District, Sleman Regency. In this parameter there are two motivations, namely being driven to meet the costs of children's education, and being motivated to meet the costs of supporting children's education in the form of bags, school clothes, shoes and school learning tools. The first motivation is being driven to meet the costs of children's education. On motivation is included in the high category with an average of 4.18. This shows that farmers are very motivated to meet the costs of their children's education, children's education becomes an important thing. Through education, we can improve the individual quality of children and have better competitiveness for children to face the future with even greater challenges. The next very important motivation that is prioritized by farmers is being pushed to meet the costs of supporting their children's education, namely to meet the needs of their children's school supplies in the form of bags, school clothes, shoes, and learning tools . Farmers are very motivated and hope that in the future their children will become more successful human beings than their parents. By meeting the various needs of various school supplies, their children become more enthusiastic in welcoming their future success. This is consistent with research which reveals that the main educational needs of OVC are school fees, exercise books and pens, school uniforms, personal needs such as shoes, toilet paper, brooms, school bags, Vaseline and lunch [29].

What is interesting is related to the motivation of tobacco farmers in meeting future needs. It can be seen that farmers are relatively less oriented in meeting future needs, they are more oriented towards meeting short-term needs, namely to meet their daily needs. Tobacco farmers in Sleman are relatively less motivated to have savings for their future needs, so the average score is in the moderate category, with a score of 3.06. P Felling trees trimming logs actually have enough desire to save money in the bank, for the sake of the future. However, not all farmers feel that their income is sufficient to save in the bank.

This shows that saving is not an urgent need that must be met by farmers and their families. Farmers do not place savings ownership as a basic need such as in meeting food needs, or clothing and housing. Saving is seen as a secondary need and is carried out when there is residual income of farmers after being used to meet various basic needs such as food, clothing and shelter. Saving is done when there is an excess of income for the farming family. Even tobacco farmers in Sleman District are less motivated to have life insurance for their families. So that the average score is only 2.59 and is included in the "low" category. Tobacco farmers seem less oriented and not motivated to have life insurance. This is understandable, because culturally (in Indonesia) insurance ownership is still poorly understood by the public. High social capital in Indonesian society has not yet develoed its use for the insurance sector. This is in accordance with the conclusion of the study that 
social capital can motivate clients to take insurance in the health sector [30]. There are still many insurance companies that have not been able to convince the public, so people are not interested in becoming their clients. results of research in Ghana suggest the underlying structural cause, however, is the lack of commitment of policy makers and implementers to pursue the equality goals of NHIS (the national health insurance scheme) [31].

Indicator of fulfillment of Relatedness Needs. Needs to be linkage (relatedness) a requirement that encourage farmers to interact and connect with other farmers or any other person other than the farmer. There are four parameters used to measure the level of motivation of farmers, namely the motivation to establish relationships with people other than farmers, motivation to increase and expand relationships with farmer groups, motivation to cooperate with other farmers, and motivation to establish relationships with agricultural extension workers as described above. Presented in Table 3.

Table 3. Scores obtained and categories of motivation on meeting the needs of interrelationships

\begin{tabular}{|c|c|c|c|c|}
\hline No & Parameter & $\begin{array}{l}\text { Score } \\
\text { Range }\end{array}$ & $\begin{array}{c}\text { Score } \\
\text { obtained }\end{array}$ & Motivation Category \\
\hline \multirow[t]{3}{*}{1.} & $\begin{array}{l}\text { Motivation to build relationships with outside } \\
\text { parties related to tobacco }\end{array}$ & & & \\
\hline & $\begin{array}{l}\text { a. Encouraged to have good relations with } \\
\text { outside parties regarding tobacco marketing }\end{array}$ & $1-5$ & 3.53 & High \\
\hline & $\begin{array}{l}\text { b. Encouraged to have } \\
\text { good relations both with providers of tobacco } \\
\text { farming needs }\end{array}$ & $1-5$ & 3.97 & High \\
\hline \multirow[t]{3}{*}{2} & $\begin{array}{l}\text { Motivation to add and expand relationships } \\
\text { with farmer groups }\end{array}$ & & & \\
\hline & $\begin{array}{l}\text { a. Encouraged to interact well with other } \\
\text { farmers }\end{array}$ & $1-5$ & 4.00 & High \\
\hline & $\begin{array}{l}\text { b. Encouraged to participate in activities held } \\
\text { by farmer groups }\end{array}$ & $1-5$ & 3.82 & High \\
\hline \multirow[t]{5}{*}{3} & Motivation to cooperate with other farmers & & & \\
\hline & $\begin{array}{l}\text { a. Encouraged to help other farmers if they } \\
\text { experience difficulties in tobacco farming } \\
\text { activities }\end{array}$ & $1-5$ & 3.53 & High \\
\hline & $\begin{array}{l}\text { b. Encouraged to provide useful information } \\
\text { to other farmers }\end{array}$ & $1-5$ & 3.79 & High \\
\hline & $\begin{array}{l}\text { c. Encouraged to get new experiences from } \\
\text { other farmers }\end{array}$ & $1-5$ & 3.53 & High \\
\hline & $\begin{array}{l}\text { d. Encouraged to get help from other } \\
\text { farmers in tobacco farming }\end{array}$ & $1-5$ & 3.76 & High \\
\hline \multirow[t]{3}{*}{4} & $\begin{array}{l}\text { Motivation to build relationships with } \\
\text { agricultural extension workers }\end{array}$ & & & \\
\hline & $\begin{array}{l}\text { a. Encouraged to dig up information about } \\
\text { tobacco farming outside of outreach activities }\end{array}$ & $1-5$ & 3.15 & Enough \\
\hline & $\begin{array}{l}\text { b. Encouraged to coordinate with agricultural } \\
\text { extension workers regarding obstacles in } \\
\text { tobacco farming independently }\end{array}$ & $1-5$ & 3.85 & High \\
\hline \multicolumn{2}{|r|}{ Amount } & $\mathbf{1 0 - 5 0}$ & 36.94 & High \\
\hline
\end{tabular}

The motivation to establish relationships with external parties related to tobacco is the first parameter used to determine the level of motivation of farmers in tobacco farming in Sleman District, Sleman Regency. There are two important aspects to the parameters of the motivation of this, namely compelled to have good relationships with outside parties related to the marketing of tobacco and encouraged have good relationships with providers of 
tobacco farming needs. The first aspect is motivated to have a good relationship with outside parties related to tobacco marketing. On aspect of this is included in the high category with an average score of 3,53. This is a good phenomenon, where there is independence from farmers to establish relationships with outside parties, especially related to tobacco marketing. Research in Mexico shows findings that small, large, part-time and full-time producers are willing to engage with farmers' markets for a variety of primary economic and non-economic motivations [32]. Individual farmers have concern and concern for the price of tobacco that he will receive. So this will be a reference for themselves and their groups to have a bargaining position in getting the best selling price. The second aspect is encouraged to have a good relationship with providers of tobacco farming needs in the future. On aspect of this is included in the high category with an average score higher, amounting to 3,97 . Based on the acquisition of a higher value in this study, based on data collected among potato farmers in Ehiopia, it was found that inut market uncertainly is more important than output market uncertainty in smallholder decisions ti participate [33]. Providers need here among others such as the need for production inputs such as fertilizers, pesticides or seed. This includes meeting the information needs and agricultural equipment. In a study in Zambia sowed that ti increase and main tain agricultural productivity, farmers need information on inputs, post harvest management and markets, as well as exposure ti new technologies and best practices [34]. Farmers have good relations with a number of parties, such as stalls providing production facilities, cooperatives and also with the Department of Agriculture. Department of agriculture here as a provider of tools help with farming tobacco, besides that, there are additional facilities from BMKG related to weather forecast. This shows that there is a strong relationship with the motivation of farmers in tobacco farming, with a good relationship it can benefit farmers to increase the efficiency of their tobacco farming activities.

Independent farmers will pay attention to both aspects. This is very important for tobacco farmers so that their farming can be sustainable. To guarantee income or profit, so that their farming can continue, farmers must be able to sell their tobacco products at a reasonable price. For this reason, farmers must have the right market and be willing to buy at a reasonable price. This phenomenon is in accordance with the concept of developing farmers. The concept of thrivin farmers - defined as those who run agribusiness ventures with the aim of maximizing profits (rather than simply stagnating at daily subsistence levels in terms of food production and supply) - is very prominent in the competitive ASEAN Economy society (MEA) [35]. Related to this, having a good relationship with potential buyers is very necessary. Farming and the cultivation of tobacco will run and proceed with smoothly if various purposes, such as the availability of production inputs (fertilizers, seeds, pesticides) or a variety of agricultural equipment requirements can be provided by either according to their needs. Thus, tobacco farmers can carry out cultivation well, can have high production, and have the potential to earn high incomes.

Motivation to add and expand relationships with farmer groups is the second parameter used to determine how much motivation level of farmers in tobacco farming is in Sleman District, Sleman Regency. Interaction is a relationship between one individual and another, as well as between individuals and groups. As social beings each individual definitely do inter action, as well as farmers tobacco also interact to keep the string frienship and nurture that relationship is maintained well. There are two aspects to this parameter, the first being motivated to interact well with other farmers and being encouraged to participate in activities held by farmer groups. The first aspect is encouraging good interaction with other farmers. On aspect of this is included in the high category with an average score of 4.00. It is shortly shows that occurred interactions are both among peers and show that there is a relationship which is closely among fellow farmers. From this good relationship, it will 
increase the sense of kinship between farmers so that when the farmers have problems or obstacles, other farmers can help provide solutions so that various problems that exist among members can be resolved properly and common goals can be achieved. The second aspect is being motivated to participate in activities held by farmer groups. On aspect of this is included in the high category with an average score of 3,82. This shows that good interactions and close relationships between fellow farmers that occur in the first aspect (encouraged to interact well with other farmers), have a positive impact on farmers' involvement in various activities held by farmer groups. Tobacco farmers actively participate in participating in extension activities, regular meetings, discussions held by farmer groups. Clear that this will certainly add insight, knowledge, and the experience of members of farmer groups, until farmers can more easily, smooth, and have the insight that continues to grow in tobacco farming activities.

The third parameter to determine the level of motivation of farmers in tobacco farming in Sleman District, Sleman Regency is the motivation to cooperate with other farmers. Working together in here can mean working together with another farmers with the same goal related activities of farming tobacco such as cooperation in the preparation seeds or work together to find various solutions to problems faced by farmers. There are four aspects that exist in this parameter, namely being motivated to help other farmers if they experience difficulties in tobacco farming activities, being encouraged to provide useful information to other farmers, being encouraged to get new experiences from other farmers, and being encouraged to get help from farmers. Others in tobacco farming. The first aspect is being motivated to help other farmers if they experience difficulties in their tobacco farming activities. This criterion is included in the high category with an average score of 3.53. This shows that farmers have a high social concern for the problems faced by their friends. Tobacco farmers always interact with other farmers in order to help fellow farmers if experiencing difficulties in tobacco farming activities. The assistance provided also varied, both in terms of knowledge related to tobacco problems, knowledge related to tobacco cultivation, seed assistance, and supporting tools related to tobacco farming. The second aspect is the incentive to provide useful information to other farmers. This criterion is included in the high category with an average score of 3.79. With group activities, not a few farmers actively participate in participating in activities organized by groups. This means that farmers get a lot of knowledge. There are other farmers who rarely took activity group, they still can obtain information by discussing and exchanging information with farmers actively obtain various information from the activities of the group. The third aspect is being motivated to get new experiences from other farmers. On these criteria are included in the high category with an average score of 3, 53. The experience of tobacco farmers another who had already experienced in farming of tobacco have an important role for the new farmers to farming tobacco. Trend of farmers are not so follow the theory presented but will be more satisfied when through and look at the experience that has been experienced by other farmers. The fourth aspect is the incentive to get help from other farmers in tobacco farming. On aspect of this is included in the high category with an average score of 3,76. The intended assistance of help means of production. Tobacco farmers in Sleman District are generally independent in procuring production facilities. If there is one farmer who for some reason gets into trouble with the means of production, it is certain that he will get help from other farmers.

The motivation to establish a relationship with the agricultural extension is a parameter last (fourth) used to measure the level of motivation of farmers in tobacco farming in the district of Sleman, Sleman Regency. Establishing a relationship with agricultural extension workers includes two aspects, namely being encouraged to dig up information about tobacco farming outside of extension activities and being encouraged to coordinate with agricultural extension workers related to obstacles in tobacco farming. The first aspect is 
being motivated to dig up information about tobacco farming outside of extension activities organized by farmer groups. The results showed that, the main role of farmer-to-farmer extension workers in motivating the younger generation was in disseminating technology and information [32]. On aspect of this is included in the category is quite high with an average score of 3,15 . In general, farmers passive to liaise individually with extension worker outside education activities organized by the group. In this study, tobacco farmers have a high enough motivation to relate to extension workers outside of group extension activities. This shows that farmers are quite independent and enthusiastic to continue to explore information about tobacco farming outside of extension activities. The second aspect is being encouraged to coordinate with agricultural extension workers regarding the obstacles in tobacco farming. In the aspect is included into high category with an average score of 3,85 . If farmers have problems or questions related to tobacco farming, farmers can ask, coordinate, directly with extension workers outside of extension activities. Time outside of extension activities is also more flexible to carry out discussions so that farmers feel more flexible in discussing with agricultural extension workers.

Indicators of fulfillment of requirement growth (growth). Needs to be growth (growth) is something that encourages farmers to grow and become better in the future, such as developing the potential in the hope to be useful to themselves, their families, and other people. There are five parameters that exist in determining the motivation per plant, the motivation to buy goods tertiary to the family, the motivation to improve knowledge about the farming of tobacco, the motivation to be appreciated and respected by others, the motivation for health, and motivation to have or develop businesses other tobacco farming. The average score and motivation category for meeting growth needs are presented in Table 4. Based on table 4, it can be seen that the motivation to buy tertiary goods for families is the first parameter used to determine how much motivation level of tobacco farmers in Sleman District is. Tertiary goods are complementary goods to meet the daily needs of farmers. There are three aspects to this parameter, namely being compelled to buy electronic equipment (TV, refrigerator, washing machine), being compelled to buy jewelry for the wife, and being compelled to buy a private vehicle.

The first aspect is encouraged buy electronic equipment (TV, refrigerators, washing machines). On aspect of this is included in the high category with an average score of 4,06 . This shows that farmers are motivated in tobacco farming because they want to buy electronic equipment. Life today's society household items such as electronic goods such as TVs, refrigerators and washing machines have been such a primary requirement. However, it turns out that there are still farmers who are not motivated to buy electronic goods. This farmer still thinks that these electronic items are not too important to fulfill. The second aspect is compelled to buy jewelry for the wife. On aspect is included in the high category with average achieved a score of 3,85 . This shows that farmers are motivated to cultivate tobacco because they want to buy their wife's jewelry. Jewelry has a number of important functions for the family, besides to beautify the wife or daughter, it also functions as a family savings for future needs. Deposits in the form of various jewelry as can later be sold back at a relatively fixed or even the value could be higher in the future. Gold jewelry is an investment for tobacco farmers. But as there are farmers who are not motivated to buy jewelry, because it feels not a priority in the subsistence of her. The third aspect is the urge to buy a private vehicle. In the aspect is included into high category with acquisition average score of 3,76. This shows that farmers are motivated in tobacco farming because they want to also purchase a vehicle that can be used for support the farming activities or for the purposes of the family in their daily mobility. In the current era, motorbikes have become a primary need for the mobility of tobacco farmers and their families.

Motivation to increase knowledge about tobacco farming is the second parameter used to determine how much motivation level of farmers is. There are three aspects to this 
parameter, namely being motivated to take part in counseling, being encouraged to seek information about tobacco farming with experts, and being encouraged to apply the results of counseling about tobacco farming. The first aspect is being motivated to take part in counseling. On aspect of this is included in the high category with an average score of 4, 03. This shows that farmers are encouraged to participate in activities held by extension workers to add insight and knowledge so that farmers can more easily carry out tobacco farming activities. The second aspect is being motivated to seek information about tobacco farming with the experts. In the aspect is included into high category with average achieved a score of 3, 97. This shows that farmers are motivated to know more in seeking information from experts, whether it is the head of the farmer group, the head of the farmer group association, or the agricultural extension worker. The third aspect is the encouragement to apply the results of counseling about tobacco farming. In the aspect is included into high category with acquisition average score of 4,03. This shows that farmers are motivated to apply the knowledge and insights gained from the activities of farmer groups and extension services so that farmers can applicator knowledge of those in farming activities and get good results.

Table 4. Scores obtained and categories of motivation in meeting growth needs

\begin{tabular}{|c|c|c|c|c|}
\hline No & Parameter & $\begin{array}{l}\text { Score } \\
\text { Range }\end{array}$ & $\begin{array}{c}\text { Score } \\
\text { obtained }\end{array}$ & Motivation Category \\
\hline \multirow[t]{4}{*}{1.} & $\begin{array}{l}\text { Motivation to buy tertiary goods for } \\
\text { the family }\end{array}$ & & & \\
\hline & $\begin{array}{l}\text { a. Encouraged to buy electronic } \\
\text { equipment (TV, refrigerator, washing } \\
\text { machine) }\end{array}$ & $1-5$ & 4.06 & High \\
\hline & b. Driven to buy jewelry for wife & $1-5$ & 3.85 & High \\
\hline & c. Encouraged to buy a private vehicle & $1-5$ & 3.76 & High \\
\hline \multirow[t]{4}{*}{2} & $\begin{array}{l}\text { Motivation to increase knowledge } \\
\text { about tobacco farming }\end{array}$ & & & \\
\hline & a. Encouraged to attend counseling & $1-5$ & 4.03 & High \\
\hline & $\begin{array}{l}\text { b. Encouraged to seek information } \\
\text { about tobacco farming with the } \\
\text { experts }\end{array}$ & $1-5$ & 3.97 & High \\
\hline & $\begin{array}{l}\text { c. Encouraged to apply the results of } \\
\text { counseling about tobacco farming }\end{array}$ & $1-5$ & 4.03 & High \\
\hline \multirow[t]{4}{*}{3} & $\begin{array}{l}\text { Motivation to be appreciated and } \\
\text { respected by others }\end{array}$ & & & \\
\hline & $\begin{array}{l}\text { a. Driven to change the family's } \\
\text { standard of living by farming tobacco }\end{array}$ & $1-5$ & 4.47 & Very high \\
\hline & $\begin{array}{l}\text { b. Encouraged to provide education } \\
\text { about tobacco farming activities to } \\
\text { other farmers }\end{array}$ & $1-5$ & 3.56 & High \\
\hline & $\begin{array}{l}\text { c. Encouraged to take part in decision } \\
\text { making in the group }\end{array}$ & $1-5$ & 3.29 & Enough \\
\hline \multirow[t]{3}{*}{4} & Motivation for health & & & \\
\hline & a. Encouraged to eat healthy food & $1-5$ & 4.35 & Very high \\
\hline & b. Driven to protect the environment & $1-5$ & 4.21 & Very high \\
\hline \multirow[t]{3}{*}{5} & $\begin{array}{l}\text { Motivation to own or develop a } \\
\text { business other than tobacco farming }\end{array}$ & & & \\
\hline & $\begin{array}{l}\text { a. Encouraged to } \\
\text { open other businesses from tobacco } \\
\text { farming }\end{array}$ & $1-5$ & 2.62 & Enough \\
\hline & $\begin{array}{l}\text { b. Encouraged to } \\
\text { develop other existing businesses }\end{array}$ & $1-5$ & 2.47 & Low \\
\hline
\end{tabular}




\begin{tabular}{|c|l|l|l|l|}
\hline & from tobacco farming & & & \\
\hline & Amount & $\mathbf{1 3 - 6 ~ 5}$ & $\mathbf{4 8 . 6 8}$ & High \\
\hline
\end{tabular}

The third parameter used to determine how much motivation level of tobacco farmers in Sleman is motivation to be appreciated and respected by others. There are three aspects to this parameter, namely being motivated to change the family's standard of living by farming tobacco, being encouraged to provide education about tobacco farming activities to other farmers, and being encouraged to take part in decision-making within the group. The first aspect is the incentive to change the family's standard of living by farming tobacco. On aspect of this is included in the category of very high with an average score of 4, 47. This shows that in general the farmers answered strongly agree to change the family's standard of living, because many farmers have proven the benefits of this tobacco farming income. Tobacco commodity is very helpful to improve farmer's life. However, a da also some $p$ Felling trees trimming logs less agree, because they only own a small area. This farmer reasoned that the income generated was sometimes only sufficient for basic needs and to meet several other needs. The low income of farmers makes it difficult for farmers to improve their family's standard of living. The second aspect is being encouraged to provide education about tobacco farming activities to other farmers. In the aspect is included into high category with average achieved a score of 3,56 . It shows that farmers are motivated help other farmers in the activities of the cultivation of tobacco, so that farmers collectively can produce tobacco in a more better. The third aspect is being encouraged to take part in decision making in the group. In the aspect is included into the category of pretty, with the average achieved a score of 3,29 . This means that there are some farmers who motivation to take part in the decision groups. In addition, there are some farmers who else entrust decisions taken in the meeting group to the board. Farmers believe that the management will make good and correct decisions for the development of tobacco farming.

The fourth parameter used to determine the level of motivation of tobacco farmers in Sleman is motivation for health. This parameter consists of two aspects, namely being motivated to consume healthy food and being encouraged to protect the environment. The first aspect is being encouraged to consume healthy foods. On aspect of this is included in the category of very high with an average score of 4,35 . This shows that everyone wants to consume healthy food, including tobacco farmers in Sleman, if the food consumed is healthy and nutritious, the body will always be healthy. Similarly, farmers market research in Scotland that food quality and safety are the main things consumed, therefore farmers are looking for organic and non-organic products that are grown locally and are healthier [36]. The second aspect is being driven to protect the environment. In the aspect is included into high category with the acquisition of an average score of 4,21 . This shows that farmers really take care of the environment, because a clean and healthy environment will provide a healthy quality of life for farmers and the people who live in the environment. Farmers felling trees trimming logs stay in environment are comfortable and feel protected.

The last parameter (fifth) on indicators of compliance requirement growth (growth) is motivated to have or develop a business in addition to tobacco farming. This parameter consists of two aspects, namely being motivated to open other businesses from tobacco farming and being encouraged to develop other existing businesses from tobacco farming. The first aspect is the incentive to open other businesses from tobacco farming. On aspect is included in the category enough, with an average score of 2, 62. This shows that there are some farmers who are interested in opening new businesses from tobacco farming and some other farmers are not. Farmers who are interested in opening new businesses from tobacco farming feel that some of the income they get from selling tobacco can still be set aside for business capital. Farmers who are not interested in opening a new business from tobacco farming say that the income from tobacco sales is only sufficient to meet their daily needs. In addition, opening a new business also requires new knowledge, insight and skills 
related to the business to be pioneered. The second aspect is being encouraged to develop existing businesses from tobacco farming. In the aspect is included into the category of low to average achieved a score of 2,47 . This means that tobacco farmers are not encouraged to develop other existing businesses from tobacco farming income. Generally, farmers who already have other businesses say that the income they get from tobacco farming is only enough to meet the daily needs of their families. Results of related research on disclosure of diversity in advisors messages from farmers to farmers and agricultural extension workers, indicating that The farmer's message focuses on encouraging farmers' commitment and motivation to agricultural enterprises, availability of financial resources needed for the entire production season, willingness to reinvest profits, and access to farmland for future expansion. If the results of this study can be applied to increasing motivation on indicators of meeting growth needs, then tobacco farmers in Sleman will grow and will increase the motivation of tobacco farmers in Sleman to own or develop businesses other than tobacco farming [37].

\section{Conclusions}

There are various categories of motivation in each of the parameters. In indicators fulfillment need existence (Existence), the parameter motivated to meet family food needs of each aspect categorized as very high. In the parameter motivated to meet the needs of the family clothing and shelter each aspect included in the high category. $\mathrm{P}$ there is a parameter motivated meet the cost of education of children of each aspect included in different categories, a da who fall into the category of motivation is very high, and high. In the motivation parameter to meet future needs, there are aspects that are included in the category of sufficient and low motivation. At indicator fulfillment of relatedness (Relatedness), almost all the parameters included in the high categories. Only the parameter motivated to establish contacts with agricultural extension, precisely on the aspects of encourage to out information about tobacco farm extension activities, included in the category enough. At indicator fulfillment growth, parameter motivated to purchase items for family tertiary and parameter motivated to increase knowledge about tobacco farming, all of each aspect included in the category of high motivation. In the motivational parameters for health, each aspect belongs to the category of very high motivation. Meanwhile, the motivation parameter to be appreciated and respected by others includes three aspects, each of which is included in the category of very high, high and sufficient motivation. In the parameter of motivation to own or develop a business other than tobacco farming includes two aspects, and each is included in the sufficient and low categories. It is necessary to provide guidance to the tobacco farmers in the direction of thinking about meeting future needs and motivating farmers to own or develop businesses other than tobacco farming.

It can be concluded that the Motivation farmers in farming tobacco in the district of Sleman, Sleman included in the high category, well on indicators fulfillment need existence (Existence), indicator fulfillment of relatedness (Relatedness), as well as on indicators of fulfillment growth (growth).

\section{References}

1. F. I. Dolly, K. Kismartini, and H. Purnaweni, E3S Web Conf. 31, 31 (2018).

2. R. Greiner and D. Gregg, Land Use Policy 28, 257 (2011).

3. S. Sudaryono, 122 (2004).

4. Badan Penelitian Tanaman Pemanis dan Serat Kementrian Pertanian, Balai Penelitian 
Tanaman Pemanis Dan Serat Kementrian Pertanian (Retrieved Februari 17, 2020, from Balittas Balitbangtan Kementrian Pertanian, 2010).

5. Badan Pusat Statistik Kabupaten Sleman, Kabupaten Sleman Dalam Angka 2013-2020/ Sleman Regency Figures 2013-2020 (BPS Kabupaten Sleman, Sleman, Yogyakarta, 2020).

6. S. Soekartawi, Analisis Usahtani (Universitas Indonesia (UI-Press), Jakarta, 2016).

7. A. Shinta, Ilmu Usahatani (Malang, 2011).

8. T. Hu and A. H. Lee, J. Public Health Policy 36, 41 (2015).

9. N. Ali, A. Jaffar, M. Anwer, M. Raza, and N. Ali, Int. J. Res. 2, 12 (2015).

10. A. Appau, J. Drope, F. Witoelar, R. Lencucha, and J. J. Chavez, Int. J. Environ. Res. Public Health 16, (2019).

11. A. K. M. G. Hussain, A. S. S. Rouf, S. N. Shimul, N. Nargis, T. M. Kessaram, S. M. Huq, J. Kaur, M. K. A. Shiekh, and J. Drope, Int. J. Environ. Res. Public Health 17, 1 (2020).

12. C. A. Damalas, E. B. Georgiou, and M. G. Theodorou, Int. J. Environ. Health Res. 16, 339 (2006).

13. E. K. K. Jew, A. J. Dougill, and S. M. Sallu, L. Degrad. Dev. 28, 2636 (2017).

14. C. Lamine, J. Rural Stud. 27, 209 (2011).

15. S. Nurlaela, E3S Web Conf. 232, 1 (2021).

16. I. Darnhofer and P. Walder, Encycl. Food Agric. Ethics 880 (2019).

17. H. B. Uno, Teori Motivasi Dan Pengukurannya. Analisis Di Bidang Pendidikan (Bumi Aksara, Jakarta, 2006).

18. H. Veisi, M. S. Carolan, and A. Alipour, Int. J. Agric. Sustain. 15, 303 (2017).

19. L. H. Essoussi and M. Zahaf, Qual. Mark. Res. 12, 443 (2009).

20. M. Aoki, Environ. Dev. Sustain. 16, 181 (2014).

21. B. Crawford, R. Byun, E. Mitchell, S. Thompson, B. Jalaludin, and S. Torvaldsen, Aust. Plan. 28 (2018).

22. M. G. McEachern and P. McClean, Int. J. Consum. Stud. 26, 85 (2002).

23. N. Othman, R. A. Latip, and M. H. Ariffin, Int. J. Agric. Resour. Gov. Ecol. 15, 45 (2019).

24. B. Zhu and A. Habisch, Br. Food J. 122, 465 (2020).

25. E. Kiptot, M. Karuhanga, S. Franzel, and P. B. Nzigamasabo, Int. J. Agric. Sustain. 14, 339 (2016).

26. Indardi and R. Budi Nugroho, E3S Web Conf. 232, (2021).

27. Sugiono, Metode Penelitian Kualitatif Kuantitatif Dan RnD (2013).

28. J. Vik and G. McElwee, J. Small Bus. Manag. 49, 390 (2011).

29. Ninla Elmawati Falabiba, (2019).

30. C. J. Fenenga, E. Nketiah-Amponsah, A. Ogink, D. K. Arhinful, W. Poortinga, and I. Hutter, Int. J. Equity Health 14, 1 (2015).

31. A. M. Kotoh and S. Van Der Geest, Int. J. Equity Health 15, 1 (2016).

32. R. Michel-Villarreal, E. L. Vilalta-Perdomo, and M. Hingley, Br. Food J. 122, 2089 (2020).

33. G. K. Abebe, J. Bijman, R. Kemp, O. Omta, and Tsegaye, Sci. Direct Food Policy 40, 14 (2013). 
34. D. Boyd and R. Spencer, Intenatonal Farmer to Farmer Ext. - Exp. Priv. Serv. Provid. Zambia (2021).

35. S. S. Hariadi and D. F. Widhiningsih, Int. J. Soc. Ecol. Sustain. Dev. 11, 14 (2020).

36. L. Carey, P. Bell, A. Duff, M. Sheridan, and M. Shields, Int. J. Consum. Stud. 35, 300 (2010).

37. N. A. Kwapong, D. A. Ankrah, D. Boateng-gyambiby, J. Asenso-agyemang, and L. O. Fening, Where World Comes to Learn Qual. Res. 25, 2011 (2020). 